\title{
Dynamic nature of active chromatin hubs
}

\author{
A. A. Gavrilov, E. S. Philonenko, O. V. Iarovaia, S. V. Razin
}

Institute of Gene Biology, RAS

34/5, Vavilova Str., Moscow, Russian Federation, 119334

sergey.v.razin@usa.net

\begin{abstract}
Aim. In order to get more information about organization of active chromatin hubs and their role in the regulation of gene transcription we have studied the spatial organization of the a-globin gene domain in cultured chicken erythroblasts. Methods. The chromosome conformation capture (3C) protocol was employed to analyze the $3 D$ configuration of the chicken $\alpha$-globin gene domain. Results. We have demonstrated that in the same cell population the chicken domain of $\alpha$-globin gene may be organized in two different active chromatin hubs. One of them appears essential for the activation of the $\alpha$-globin gene expression while the other-for the activation of TMEM8 gene which constitutes a part of the $\alpha$-globin gene domain in chicken, but not in human and other mammals. Importantly, two regulatory elements participate in the formation of both active chromatin hubs. Conclusions. The assembly of the same genomic area into two alternative chromatin hubs which share some regulatory elements suggests that active chromatin hubs are dynamic rather than static, and that regulatory elements may shuttle between different chromatin hubs.
\end{abstract}

Keywords: active chromatin hub, globin gene, genomic domain, chromosome conformation capture.

Introduction. Although the mechanism of enhancer action is far from being clear, most of the current models postulate that an enhancer physically interacts with the target promoter, while sometimes it is located a considerable distance away, up to several hundred kilobases. Therefore, the segment of the chromatin fibre that separates the promoter and the enhancer must be looped out. In multigene loci a single enhancer or block of enhancers (locus control region) appears to activate simultaneously several promoters. For example, in erythroid cells of adult lineage, the mouse $\beta$-globin locus control region (LCR) stimulates expression of both the $\beta$-major and $\beta$-minor globin genes. The promoters of these genes are located at a distance of $14 \mathrm{~kb}$ from each other and could not simultaneously interact with the same LCR if only a single loop was formed. It was therefore proposed that LCR forms short-living alternating complexes with these promoters $[1,2]$.

(C) Institute of Molecular Biology and Genetics, NAS of Ukraine, 2011
Another model postulates association of an LCR and several depended promoters in an active chromatin hub, a multicomponent complex, from which several chromatin segments are looped out $[3,4]$. This model, although presently widely accepted [3, 4], still remains hypothetical due to the intrinsic limitations of the chromosome conformation capture (3C) approach, which can only establish pairwise interactions between distant chromosome elements [5]. Thus, multicomponent chromatin hubs can be only predicted, not proved, based on the results of $3 \mathrm{C}$ analysis. Besides, most of the present knowledge about active chromatin hubs is based on the studies of one model system, the murine domain of $\beta$-globin genes $[4,6-8]$. In order to get more insights into the nature of active chromanin hubs we studied the spatial organization of the $\alpha$-globin gene domain in chicken erythroid cells producing globins of an adult type. The results obtained demonstrate that in this domain two alternative active chromatin hubs may be assembled. Most interesting, two regulatory elements 
(the $-9 \mathrm{~kb}$ DNase I hypersensitive site ( $-9 \mathrm{~kb}$ DHS) and the downstream enhancer) participate in the formation of both active chromatin hubs. They should thus shuttle between these hubs as predicted by the «flip-flop» model $[1,2]$.

Materials and methods. Cell culture. The avian erythroblastosis virus-transformed chicken erythroblast cells HD3 (clone A6 of line LSCC [9]) were grown in Dulbecco's modified Eagle's medium (DMEM) supplemented with $2 \%$ chicken serum and $8 \%$ fetal bovine serum (FBS) at $37{ }^{\circ} \mathrm{C}$ with $5 \% \mathrm{CO}_{2}$.

To induce terminal erythroid differentiation, HD3 cells at a density of $1 \cdot 10^{6}$ cells $/ \mathrm{ml}$ were incubated in the above medium additionally containing $10 \mathrm{mM}$ HEPES (pH 8.0) and $20 \mu \mathrm{M}$ iso-H-7 (1-(5-Isoquinolinylsulfonyl)-3-methylpiperazine dihydrochloride, «Fluka», Switzerland) at $42{ }^{\circ} \mathrm{C}$ in $100 \%$ air atmosphere [10]. The cells were collected in $12 \mathrm{~h}$ after the beginning of induction.

$3 \mathrm{C}$ analysis. $3 \mathrm{C}$ analysis was performed as described $[11,12]$. A random-ligation control was generated using DNA of a bacterial artificial chromosome containing the chicken $\alpha$-globin gene domain along with the flanking areas (Gallus gallus BAC clone CH26175C12, CHORI BACPAC Resources Center).

The ligation products were analysed using the realtime PCR with TaqMan probes. Primers and TaqMan probes for PCR analysis were designed using the DNA sequence of Gallus gallus BAC clone CH261-75C12 (AC172304, GeneBank) and Primer Premier 5 computer software (PRIMER Biosoft International). The sequences of the primers and TaqMan probes are available upon request. Each PCR reaction was carried out in quadruple repetition and the corresponding results were averaged. Once a resulting $3 \mathrm{C}$ curve representing the spectrum of interactions between an anchor fragment and other fragments throughout the domain was obtained, the experiments starting with living cells were repeated twice more in order to check the reproducibility of the results.

To take into account the differences in the efficiency of crosslinking/restriction/ligation and in the quantity of DNA in the $3 \mathrm{C}$ templates obtained from cells of different types, the internal standard was used [11]. A house-keeping gene $E R C C 3$ situated on another chicken chromosome was chosen as such a standard.
Results and discussion. The domain of chicken $\alpha$ globin genes (Fig. 1, $A$ ) contains three alpha-type globin genes and several regulatory elements, including the major regulatory element (MRE) of the domain located in an intron of the apparently house-keeping gene C16orf35, and the downstream enhancer located right after the $\alpha^{A}$ gene. We have demonstrated that this domain also harbors a non-globin gene TMEM8. It was relocated to the vicinity of the $\alpha$-globin cluster due to the inversion of a $\sim 170-\mathrm{kb}$ genomic fragment. Although in humans TMEM8 is preferentially expressed in resting T-lymphocytes, in chickens it acquires an erythroid-specific expression profile and is upregulated upon terminal differentiation of erythroblasts [13]. In the intron 7 of chicken TMEM8 gene an erythroid-specific enhancer is located [13].

AEV-transformed chicken erythroblasts (line HD3, clone A6 of line LSCC) correspond to chicken hemopoietic cells of the red lineage arrested at early stages of differentiation $[9,14]$. They do not express globin genes, although the $\alpha$-globin gene domain resides in an active configuration supported by low-level transcription of the whole domain [15]. After induction of terminal erythroid differentiation, HD3 cells stop proliferation and start production of globins. To study the spatial organization of the $\alpha$-globin gene domain in proliferating and differentiated HD3 cells we used the 3C method [5, 8, 16]. The combination of BglII and BamHI restriction enzymes was used for $3 \mathrm{C}$ analysis. These enzymes recognize different consensuses but produce compatible DNA ends which can be crossligated.

We first investigated the interaction of the LCRlike MRE with each of the downstream restriction fragments (with the exception of very short fragments). As shown in Fig. 1, $B$, in both proliferating and differentiated HD3 cells this element interacts with the $-9 \mathrm{~kb}$ DHS, the upstream CpG island of the $\alpha$-globin gene cluster and the $\alpha^{D}$ gene promoter. In differentiated (i. e. expressing globins) HD3 cells the frequencies of all above-mentioned interactions increased. In addition, a clear interaction between the MRE element and the downstream enhancer was established. Notably, the MRE did not interact with upstream $\mathrm{CpG}$ island of TMEM8 gene and with the enhancer located in the body of TMEM 8 gene (Fig. 1, B). In contrast, in experiments 

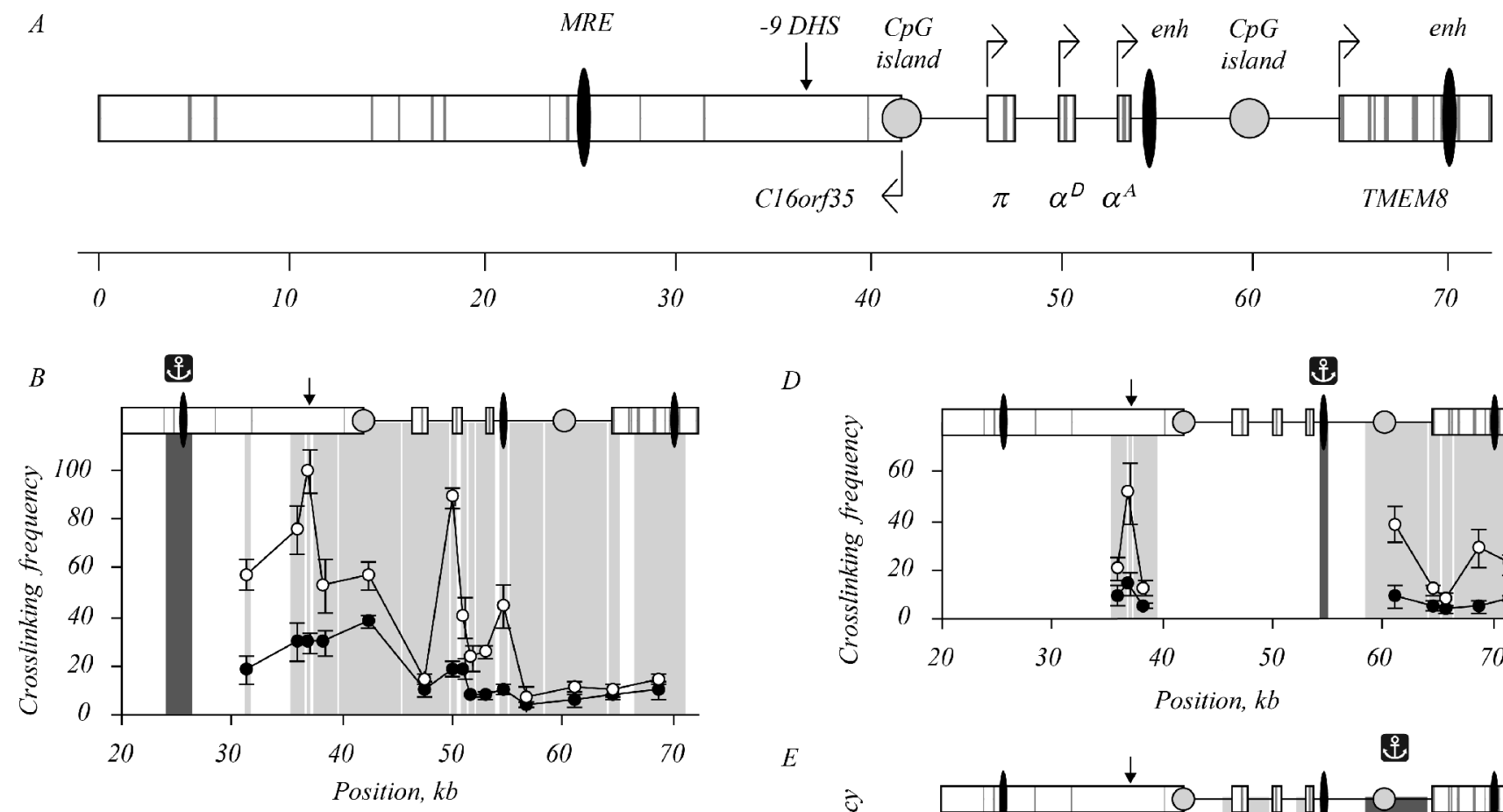

$D$

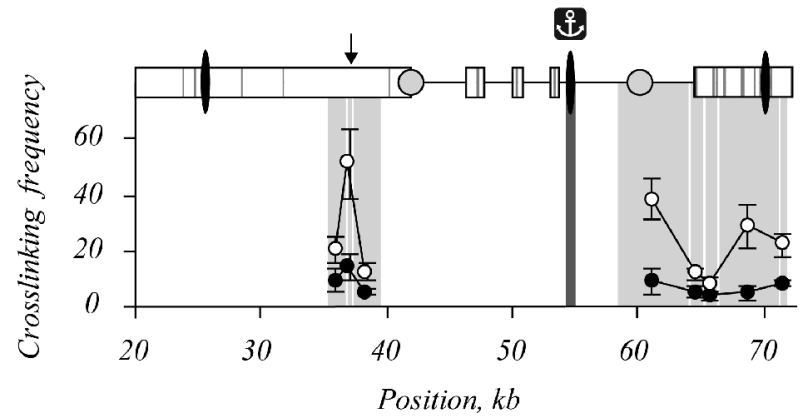

$E$
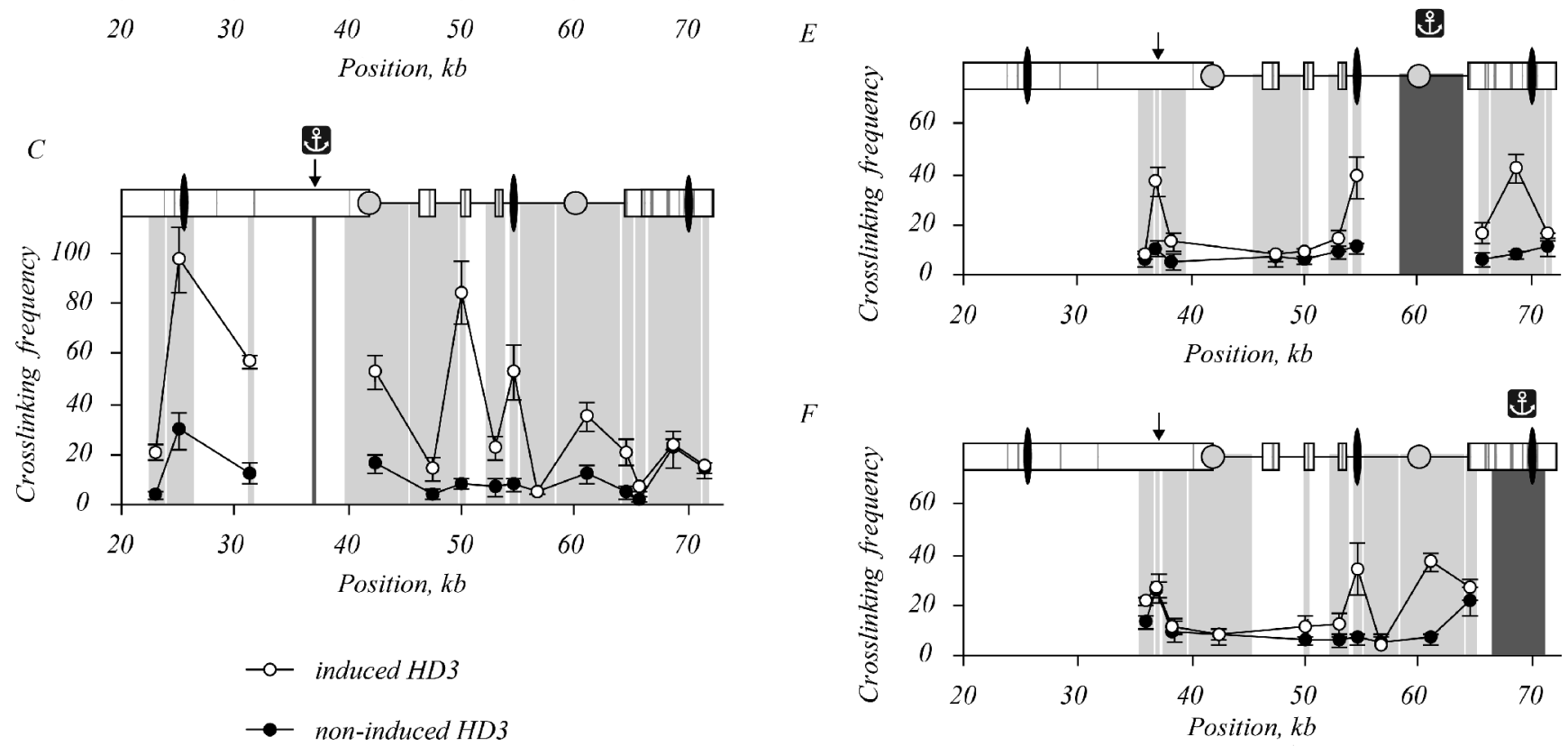

Fig. 1. 3C analysis of the chicken $\alpha$-globin gene domain: $A$ - the scheme showing positions of important functional elements in the chicken $\alpha$-globin gene domain (the scale is in $\mathrm{kb}$ and « $0 »$ point of the scale is arbitrary placed at the 3 '-end of the $C 16$ orf 35 gene); $B-F-$ relative frequencies of cross-linking between the anchor fragments bearing $B$-MRE; $C--9 \mathrm{~kb}$ DHS; $D$ - the downstream enhancer of the $\alpha$-globin gene domain; $E$ - the upstream CpG island of the TMEM8 gene; $F$ - the erythroid-specific enhancer located in the body of the TMEM gene and other fragments of the locus. The $x$ axis shows distances in kb. On the top of each graph a scheme of the domain with the same symbols as in $A$ is shown. The results of $3 \mathrm{C}$ analysis for cycling (non-induced) and differentiated (induced) HD3 cells are shown by closed and open circles, respectively. The frequency of cross-linking the fragment bearing MRE with the fragment bearing $-9 \mathrm{~kb}$ DHS in differentiated HD3 cells was taken to equal 100 relative units. The dark gray rectangle in the background of each graph with the anchor drawn above indicates a fixed (anchor) DNA fragment, and the light gray rectangles - test-fragments. Error bars represent SEM

with the anchor fixed at the -9 DHS or at the downstream enhancer of the $\alpha$-globin gene domain the interactions with the $\mathrm{CpG}$ island of TMEM8 gene and with the enhancer located in the body of TMEM 8 gene were clearly visible (Fig. 1, C, D). Again, the apparent frequency of the interactions was much more prominent in differentiated HD3 cells. The significance of the above-described observations was verified in reciprocal 


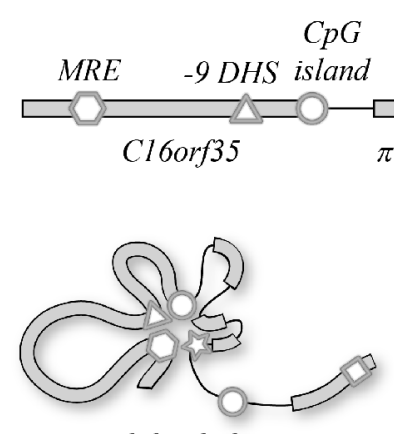

globin hub
$C p G$

enh island $\pi \quad \alpha^{D} \alpha^{\Lambda}$

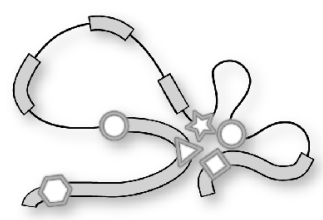

TMEM hub
Fig. 2. Configuration of the two alternative active chromatin hubs described in this article

experiments when the anchor was placed on the $\mathrm{CpG}$ island of TMEM 8 gene and on the enhancer situated in the body of TMEM 8 gene (Fig. 1, E, F).

Taking together, the results of our $3 \mathrm{C}$ analysis can not be explained by the assembly of a single activation complex harboring all known regulatory elements of the $\alpha$-globin gene domain. There should exist at least two alternative activation complexes stimulating expression of globin genes and of TMEM8 gene (Fig. 2). The «globin hub» includes the MRE, the $-9 \mathrm{~kb}$ upstream DHS, the $-4 \mathrm{~kb}$ upstream CpG island of the $\alpha$ globin gene domain, the $\alpha^{D}$ gene promoter and the downstream enhancer. The «TMEM8 hub» includes the $-9 \mathrm{~kb}$ DHS, the downstream enhancer, the upstream CpG island of the TMEM 8 gene and the erythroid-specific enhancer located in one of the TMEM8 gene introns. Two regulatory elements (the $-9 \mathrm{~kb}$ DHS and the downstream enhancer) participate in the formation of both active chromatin hubs. They should thus shuttle between these hubs as predicted by the «flip-flop» model $[1,2]$. This model was proposed to explain the ability of the $\beta$-globin gene domain LCR to activate transcription of several genes which appeared to be transcribed simultaneously. Although this model was never disproved, it was almost forgotten after advancement of the active chromatin hub model $[4,6-8,17]$. Indeed, the assembly of several enhancers and promoters into a single active chromatin hub suggests a simpler explanation for the ability of an enhancer to activate simultaneously several promoters.

Our data suggest that the two models are not mutually exclusive, and that chromatin hubs should be regarded as dynamic rather than static.
Acknowledgements. This work was supported by the Ministry of Science and Education of the Russian Federation (contracts 16.740.11.0353 and 16.740.11. 0483 ) and by Russian Foundation for Support of Basic Researches (grants 11-04-00361-a and 11-04-91334NNIO_a).

\section{О. А. Гаврилов, О. С. Филоненко, О. В. Яровая, С. В. Разин}

Динамічна природа активаторних хроматинових блоків

Резюме

Мета. Щоб отримати нову інформацію стосовно організації активаторних хроматинових блоків та їхньої ролі в регуляції транскрипиї ми вивчили просторову організаџію домену а-глобінових генів у культивованих курячих еритробластах. Методи. Для анализу $3 D$ конфігураиії домену $\alpha$-глобінових генів використано метод фіксаиії конформаиії хромосоми (3С). Результати. Ми продемонстрували, що в одній $і$ тій самій популяиії курячих клітин домен $\alpha$-глобінових генів може бути організованим у два різних хроматинових блоки. Один з них необхідний для активаџї̈ транскрипиії $\alpha$-глобінових генів, тоді як другий забезпечує активачію транскрипиії гена ТМЕМ8. Цей ген входить до складу домену $\alpha-$ глобінових генів курей, але не ссавиів і людини. Важливо, щңо два регуляторних елементи домену $\alpha$-глобінових генів присутні у складі обох активаторних хроматинових блоків. Висновки. Існування в одному й тому ж геномному домені двох різних активаторних комплексів, які мають у своєму складі спільні регуляторні елементи, свідчить про динамічну природу активаторних хроматинових блоків, що дозволяє спільним регуляторним елементам періодично переміщуватися з одного комплексу в другий.

Ключові слова: активаторні хроматинові блоки, глобіновий ген, геномний домен, метод фіксації хромосоми.

\section{А. А. Гаврилов, Е. С. Филоненко, О. В. Яровая, С. В. Разин}

Динамическая природа активаторных хроматиновых блоков Резюме

Цель. Чтобы получить новую информацию об организации активаторных хроматиновых блоков и их роли в регуляции транскрипuии, мы изучили пространственную организацию домена $\alpha$-глобиновых генов в культивируемых куриных эритробластах. Методы. Для анализа $3 D$ конфигурачии домена $\alpha$-глобиновых генов использован метод фиксации конформации хромосомы (3С). Результаты. Мы продемонстрировали, что в одной и той же популяции куриных клеток домен $\alpha$-глобиновых генов может быть организован в два различных хроматиновых блока. Один из них необходим для активачии транскрипщии $\alpha$-глобиновых генов, в то время как другой обеспечивает активацию транскрипиии гена TMEМ8. Этот ген входит в состав домена $\alpha$-глобиновых генов кур, но не млекопитающих и человека. Важно, что два регуляторных элемента домена $\alpha$-глобиновых генов присутствуют в составе обоих активаторных хроматиновых блоков. Выводы. Существование в одном и том же геномном домене двух разных активаторных комплексов, имеющих в своем составе общие регуляторные элементы, свидетельствует о динамической природе активаторных хроматиновых блоков, что позволяет общим ре- 
гуляторным элементам периодически перемещчаться из одного комплекса в другой.

Ключевые слова: активаторные хроматиновые блоки, глобиновый ген, геномный домен, метод фиксации хромосомы.

\section{REFERENCES}

1. Wijgerde M., Grosveld F., Fraser P. Transcription complex stability and chromatin dynamics in vivo // Nature.-1995.-377, N 6546.-P. 209-213.

2. Gribnau J., de Boer E., Trimborn T., Wijgerde M., Milot E., Grosveld F., Fraser P. Chromatin interaction mechanism of transcriptional control in vivo // EMBO J.-1998.-17, N 20.P. 6020-6027.

3. Palstra R. J., de Laat W., Grosveld F. Beta-globin regulation and long-range interactions // Adv. Genet.-2008.-61.-P. 107142.

4. de Laat W., Klous P., Kooren J., Noordermeer D., Palstra R. J., Simonis M., Splinter E., Grosveld F. Three-dimensional organization of gene expression in erythroid cells // Curr. Top. Dev. Biol.-2008.-82.-P. 117-139.

5. Dekker J., Rippe K., Dekker M., Kleckner N. Capturing chromosome conformation // Science.-2002.-295, N 5558.-P. 13061311 .

6. Kooren J., Palstra R. J., Klous P., Splinter E., von Lindern M., Grosveld $F$., de Laat $W$. Beta-globin active chromatin Hub formation in differentiating erythroid cells and in p45 NF-E2 knock-out mice // J. Biol. Chem.-2007.-282, N 22.-P. 16544 16552.

7. de Laat W., Grosveld F. Spatial organization of gene expression: the active chromatin hub // Chromosome Res.-2003.-11, N 5.P. 447-459.

8. Tolhuis B., Palstra R. J., Splinter E., Grosveld F., de Laat W. Looping and interaction between hypersensitive sites in the active beta-globin locus // Mol. Cell.-2002.-10, N 6.-P. 1453-1465.

9. Beug H., von Kirchbach A., Doderlein G., Conscience J. F., Graf $T$. Chicken hematopoietic cells transformed by seven stra- ins of defective avian leukemia viruses display three distinct phenotypes of differentiation // Cell.-1979.-18, N 2.-P. 375-390.

10. Nicolas R. H., Partington G., Major G. N., Smith B., Carne A. $F$., Huskisson N., Goodwin G. Induction of differentiation of avian erythroblastosis virus-transformed erythroblasts by the protein kinase inhibitor $\mathrm{H} 7$ : analysis of the transcription factor EF1 // Cell Growth Differ.-1991.-2, N 3.-P. 129-135.

11. Splinter E., Grosveld F., de Laat W. 3C technology: analyzing the spatial organization of genomic loci in vivo // Methods Enzymol.-2004.-375.-P. 493-507.

12. Gavrilov A. A., Razin S. V. Spatial configuration of the chicken alpha-globin gene domain: immature and active chromatin hubs // Nucleic Acids Res.-2008.-36, N 14.-P. 4629-4640.

13. Filonenko E. S., Gavrilov A. A., Razin S. V., Iarovaia O. V. Expansion of the functional domain of chicken alpha-globin genes // Genetika.-2010.-46, N 9.-P. 1164-1167.

14. Beug H., Doederlein G., Freudenstein C., Graf T. Erythroblast cell lines transformed by a temperature-sensitive mutant of avian erythroblastosis virus: a model system to study erythroid differentiation in vitro // J. Cell Physiol. Suppl.-1982.-1.P. 195-207.

15. Razin S. V., Rynditch A., Borunova V., Ioudinkova E., Smalko $V$., Scherrer $K$. The $33 \mathrm{~kb}$ transcript of the chicken alpha-globin gene domain is part of the nuclear matrix // J. Cell Biochem.2004.-92, N 3.-P. 445-457.

16. Liu Z., Garrard W. T. Long-range interactions between three transcriptional enhancers, active Vkappa gene promoters, and a 3' boundary sequence spanning 46 kilobases // Mol. Cell Biol.2005.-25, N 8.-P. 3220-3231.

17. Zhou G. L., Xin L., Song W., Di L. J., Liu G., Wu X. S., Liu D. P., Liang C. C. Active chromatin hub of the mouse alpha-globin locus forms in a transcription factory of clustered housekeeping genes // Mol. Cell Biol.-2006.-26, N 13.-P. 5096-5105.

UDC 577.21

Received 27.07.2011 